\title{
Assessment of Human Gingival Fibroblast Proliferation after Laser Stimulation In Vitro Using Different Laser Types and Wavelengths (1064, 980, 635, 450, and $405 \mathrm{~nm})$-Preliminary Report
}

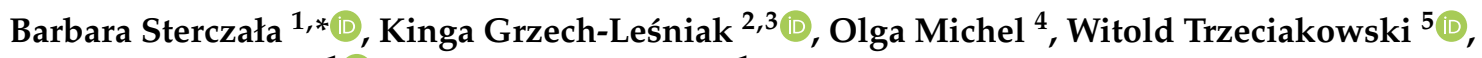 \\ Marzena Dominiak $^{1}$ and Kamil Jurczyszyn ${ }^{1}$
}

check for updates

Citation: Sterczała, B.; Grzech-Leśniak, K.; Michel, O.; Trzeciakowski, W.;

Dominiak, M.; Jurczyszyn, K.

Assessment of Human Gingival

Fibroblast Proliferation after Laser Stimulation In Vitro Using Different Laser Types and Wavelengths (1064, 980, 635, 450, and $405 \mathrm{~nm}$ )— Preliminary Report. J. Pers. Med. 2021, 11, 98.

https://doi.org/10.3390/jpm11020098

Academic Editor: Susan M Bailey

Received: 20 January 2021

Accepted: 2 February 2021

Published: 4 February 2021

Publisher's Note: MDPI stays neutral with regard to jurisdictional claims in published maps and institutional affiliations.

Copyright: (c) 2021 by the authors. Licensee MDPI, Basel, Switzerland. This article is an open access article distributed under the terms and conditions of the Creative Commons Attribution (CC BY) license (https:// creativecommons.org/licenses/by/ $4.0 /)$.
1 Dental Surgery Department, Wroclaw Medical University, 50-425 Wroclaw, Poland; marzena.dominiak@umed.wroc.pl (M.D.); kjurczysz@interia.pl (K.J.)

2 Laser Laboratory at Dental Surgery Department, Wroclaw Medical University, 50-425 Wroclaw, Poland; kgl@periocare.pl

3 Department of Periodontics, School of Dentistry, Virginia Commonwealth University, VCU, Richmond, VA 23298, USA

4 Department of Molecular and Cell Biology, Wroclaw Medical University, 50-556 Wroclaw, Poland; WF-26@umed.wroc.pl

5 Institute of High Pressure Physics, Polish Academy of Sciences, 01-142 Warsaw, Poland; wt@unipress.waw.pl

* Correspondence: barbara.sterczala@op.pl; Tel.: +48-502-932-269
Abstract: Purpose: to assess the effect of photobiomodulation (PBM) on human gingival fibroblast proliferation. Methods: The study was conducted using the primary cell cultures of human fibroblasts collected from systemically healthy donors. Three different laser types, Nd:YAG (1064 nm), infrared diode laser (980 nm), and prototype led laser emitting 405, 450, and $635 \mathrm{~nm}$ were used to irradiate the fibroblasts. Due to the patented structure of that laser, it was possible to irradiate fibroblasts with a beam combining two or three wavelengths. The energy density was $3 \mathrm{~J} / \mathrm{cm}^{2}, 25 \mathrm{~J} / \mathrm{cm}^{2}, 64 \mathrm{~J} / \mathrm{cm}^{2}$. The viability and proliferation of cells were determined using the (Thiazolyl Blue Tetrazolium Blue) (MTT) test conducted 24, 48, and $72 \mathrm{~h}$ after laser irradiation. Results: The highest percentage of mitochondrial activity $(\mathrm{MA}=122.1 \%$ ) was observed in the group irradiated with the $635 \mathrm{~nm}$ laser, with an energy density of $64 \mathrm{~J} / \mathrm{cm}^{2}$ after $48 \mathrm{~h}$. The lowest percentage of MA (94.0\%) was observed in the group simultaneously irradiated with three wavelengths $(405+450+635 \mathrm{~nm})$. The use of the $405 \mathrm{~nm}$ laser at $25 \mathrm{~J} / \mathrm{cm}^{2}$ gave similar results to the $635 \mathrm{~nm}$ laser. Conclusions: The application of the $635 \mathrm{~nm}$ and $405 \mathrm{~nm}$ irradiation caused a statistically significant increase in the proliferation of gingival fibroblasts.

Keywords: cell proliferation; human gingival fibroblasts; photobiomodulation; PBM; soft tissue regeneration

\section{Introduction}

Nowadays, laser has become an indispensable tool in the dental office [1-3]. It is used as a treatment device that has replaced surgical instruments such as the scalpel; it improves the patient's postoperative comfort by minimizing pain and swelling [4]. Depending on the type, the laser may be used in the area of soft and hard tissues. It is used, for instance, in orthodontics, in the treatment of temporomandibular joint dysfunctions and implantological rehabilitation [5-9]. Moreover, lasers have been demonstrated to support the treatment of snoring and sleep apnea, as well as periodontal diseases, e.g., peri-implantitis [10-17]. The effects of laser photobiomodulation (PBM) in muco-gingival surgery are relatively well established [18-20].

The mechanism of action of laser PBM at the cellular level is based on the simultaneous activation of many reactions. The structure and function of biological membranes are modified, endorphins are released, and an increase in the activity of the immune system of cells 
and enzymes is observed [21]. A signaling cascade is triggered by the electron transfer between five protein complexes found in the mitochondrial membrane. The above mentioned membrane proteins include NADH dehydrogenase, succinate dehydrogenase, cytochrome c reductase, cytochrome c oxidase, and adenosine triphosphate (ATP) synthetase, as well as free molecules like ubiquinone and cytochrome c. Metabolic processes are activated in the mitochondria that stimulate chromophores in the mitochondrial respiratory chain and induce an increase in the production of ATP [22-24]. The intensification of cellular respiration contributes to the growth, migration, differentiation, and proliferation of cells within the wound, including fibroblasts. The bioactive mediators released by fibroblasts, e.g., growth factors, affect the metabolism of cells by synthesizing components of the extracellular matrix such as collagen type I [25-27]. In addition to being important for wound healing or tissue regeneration, PBM influences angiogenesis by generating vascular endothelial growth factor (VEGF) $[28,29]$. Changes at the cellular and biochemical levels can evoke therapeutic effects due to the stimulation of wound healing, anti-inflammatory and analgesic action, as well as prevention of swelling and tissue necrosis [30].

The improved knowledge of tissue biomimetics has introduced significant changes in periodontological plastic surgery, which contributed to the development of new tools in the form of primary cell culture of fibroblasts [31]. This method involves obtaining autogenous tissue in quantities determined by its shortage. Isolated and cultured gingival fibroblasts can be implanted on various types of matrices, both xenogenic (collagen 3D) and allogenic (fascia lata) ones [32]. In the form of a hydrated cell matrix, they are implanted in the recipient site, e.g., the augmentation of the keratinized gingival performed on a thin biotype before planned orthodontic treatment, implant, or prosthetic rehabilitation [33]. This method undoubtedly makes it possible to reduce the invasiveness of the procedure resulting from the minimal recipient site $\left(2 \mathrm{~mm}^{2}\right)$ and gives quick final results thanks to short breeding time which is up to 10 days. In addition, the site of augmentation does not lead to excessive tension or thickening of the mucous membrane and the creation of scarring features, which is important in the aesthetic aspect of treatment [34]. This method may be a clinically satisfactory alternative to autogenous connective tissue transplantation, while maintaining the indication for its use. Importantly, this method makes it possible to obtain the optimal amount of fibroblasts. In their histological studies, Dominiak et al. (2010) proved that the optimal amount of autogenous fibroblasts implanted on the collagen matrix accelerates the wound healing process and affects the generation of angiogenesis and the elimination of features of scarring [35]. The PBM mechanism indicates that this is an appropriate technique to obtain more fibroblasts, and indirectly, growth factors for soft tissue regeneration. Therefore, research is being conducted to optimize irradiation parameters in specific clinical procedures. Most reports represent the use of radiation for biostimulation in the range of low-power light which should not increase the temperature by more than $5{ }^{\circ} \mathrm{C}$. An increase in the temperature may lead to significant changes in the structure of the cell membrane, such as the minimized activity of the sodium-potassium pump and reduced flow of calcium ions, which in turn leads to a decrease in the amount of cyclic ATP. Reduced oxidative phosphorylation and limited DNA and RNA synthesis result in the reduction of cell proliferation and functioning of the immune system.

The aim of this in vitro study was to compare the effect of different wavelengths: $405 \mathrm{~nm}, 450 \mathrm{~nm}$, and $635 \mathrm{~nm}$ as well as their combinations-980 nm and $1064 \mathrm{~nm}$ on the proliferation of human fibroblasts.

\section{Materials and Methods}

\subsection{Cell Culture}

This study was approved by the Ethics Committee of Wroclaw Medical University, Poland (No KB-434/2017).

The study was conducted using the primary cell cultures of human fibroblasts collected from systemically healthy donors, from the hard palate. Tissue was collected from an area of $1-2 \mathrm{~mm}^{2}$ and transported to the laboratory in the nutrient medium Dulbecco's 
Modified Eagle Medium (DMEM, Sigma-Aldrich, Poznan, Poland) with the addition of $10 \%$ fetal calf serum, penicillin $(100 \mathrm{Ul} / \mathrm{mL})$, streptomycin $(0.1 \mathrm{mg} / \mathrm{mL})$, and amphotericin B $(0.1 \mathrm{mg} / \mathrm{mL})$. Next, fibroblasts were isolated and cultured according to the procedure developed by Polish scientists M. Dominiak and J. Saczko, Patent No. 381204 (Saczko, 2008), based on the mechanical isolation, which affects cellular biomechanics [34]. The culture was carried out in a conventional DMEM culture medium in an incubator at $37^{\circ} \mathrm{C}$ in a $5 \% \mathrm{CO}_{2}$ atmosphere. The culture medium was changed twice a week. The cells reached a full monolayer after 5-7 days. For the purposes of laser irradiation, fibroblasts were subjected to trypsinisation ( $0.25 \%$ trypsin-EDTA, Sigma-Aldrich, Poznan, Poland) and seeded into 96-well plates for further examination.

\subsection{Laser Irradiation}

Three lasers were used to irradiate fibroblasts. One of them was the Nd:YAG laser (LightWalker, Fotona, Slovenia) with a flat-top handpiece (Genova, LightWalker, Fotona, Slovenia). This handpiece produces a spot with a diameter of $10 \mathrm{~mm}$ (which is exactly the diameter of the wells in the culture plates) and with a homogeneous beam profile. The other two lasers were a diode laser of $980 \mathrm{~nm}$ (Smart M, Lasotronix, Poland, Piaseczno, Poland), and a diode laser constructed by Trzeciakowski et al. from the Polish Academy of Sciences (Patent No.: 9,223,123). Eight laser diode beams are coupled into a multi-mode fiber (with a 100-400 $\mu \mathrm{m}$ core) using a reflector in the form of a regular pyramid (Ivonyak et al., 2014). The optimization of the optical system enables the coupling of $60-90 \%$ of light into the fiber. In the laser developed for the project, we used three wavelengths emitted by 8 diodes:

3 diodes emitting at $405 \mathrm{~nm}$ (maximum output power of $0.70 \mathrm{~W}$ ),

2 diodes emitting at $450 \mathrm{~nm}$ (maximum output power of $1.0 \mathrm{~W}$ ),

3 diodes emitting at $635 \mathrm{~nm}$ (maximum output power of $1.0 \mathrm{~W}$ ).

Since all laser diodes were coupled into the same fiber, it was possible to irradiate fibroblasts with a beam combining one, two, or three wavelengths. Exposure was carried out using the headset at right angle to the samples and at a distance of $5 \mathrm{~mm}$ from the cells. The parameters used in the study are presented in Table 1 . In case of both commercial lasers (Light Walker Fotona and Smart M, Lasotronix), the output power was determined on the basis of energy density, so we set power settings of the prototype laser to values similar to those of the commercial laser parameters. To achieve the same energy density (ED), the time of irradiation was varied. In case of pulsed mode in all lasers, the frequency was $10 \mathrm{~Hz}$, and the duty cycle was $50 \%$. In case of two or three wavelengths in one irradiation, the power was equally distributed between each wavelength.

Table 1. Parameters of: Nd:YAG (LightWalker Fotona, Slovenia), $980 \mathrm{~nm}$ diode laser (Smart M, Lasotronix, Poland), and Visible laser developed for the project (Poland).

\begin{tabular}{|c|c|c|c|c|c|}
\hline \multirow{2}{*}{ Type of Laser } & \multirow{2}{*}{ Wavelength } & \multicolumn{3}{|c|}{ Output Power for Energy Density } & \multirow{2}{*}{$\begin{array}{l}\text { Pulse Modulation- } \\
\text { Frequency }\end{array}$} \\
\hline & & $3 \mathrm{~J} / \mathrm{cm}^{2}$ & $25 \mathrm{~J} / \mathrm{cm}^{2}$ & $64 \mathrm{~J} / \mathrm{cm}^{2}$ & \\
\hline $\begin{array}{c}\text { Nd-YAG } \\
\text { (Light-Walker } \\
\text { Fotona, Slovenia) }\end{array}$ & $1064 \mathrm{~nm}$ & $0.25 \mathrm{~W}$ & $0.5 \mathrm{~W}$ & $1.0 \mathrm{~W}$ & \multirow{2}{*}{$10 \mathrm{~Hz}$} \\
\hline $\begin{array}{l}\text { Diode laser (Smart M, } \\
\text { Lasotronix Poland) }\end{array}$ & $980 \mathrm{~nm}$ & $0.50 \mathrm{~W}$ & $1.0 \mathrm{~W}$ & $2.0 \mathrm{~W}$ & \\
\hline \multirow{6}{*}{$\begin{array}{l}\text { Visible diode laser } \\
\text { developed for the } \\
\text { project (Poland) }\end{array}$} & $405 \mathrm{~nm}$ & $0.25 \mathrm{~W}$ & $0.5 \mathrm{~W}$ & $0.7 \mathrm{~W}$ & \multirow{6}{*}{$10 \mathrm{~Hz}$} \\
\hline & $450 \mathrm{~nm}$ & $0.25 \mathrm{~W}$ & $0.5 \mathrm{~W}$ & $1.0 \mathrm{~W}$ & \\
\hline & $635 \mathrm{~nm}$ & $0.25 \mathrm{~W}$ & $0.5 \mathrm{~W}$ & $1.0 \mathrm{~W}$ & \\
\hline & $405+635 \mathrm{~nm}$ & $0.15 \mathrm{~W}+0.15 \mathrm{~W}$ & $0.25 \mathrm{~W}+0.25 \mathrm{~W}$ & $0.5 \mathrm{~W}+0.5 \mathrm{~W}$ & \\
\hline & $450+635 \mathrm{~nm}$ & $0.15 \mathrm{~W}+0.15 \mathrm{~W}$ & $0.25 \mathrm{~W}+0.25 \mathrm{~W}$ & $0.5 \mathrm{~W}+0.5 \mathrm{~W}$ & \\
\hline & $405+450+635 \mathrm{~nm}$ & $0.10 W+0.10 W+0.10 W$ & $0.15 W+0.15 W+0.15 W$ & $0.35 W+0.35 W+0.35 W$ & \\
\hline
\end{tabular}


Before the irradiation, the cells were seeded on the black 96-well plates, at $\sim 5 \times 10^{3}$ cells per well. The distribution of cells in the wells also depended on power to avoid accidental exposure of cells from an adjacent well. In the case of an energy density of $3 \mathrm{~J} / \mathrm{cm}^{2}$, the cells were located every third well, in case of energy density of $25 \mathrm{~J} / \mathrm{cm}^{2}$ - every six wells, and in case of energy density of $64 \mathrm{~J} / \mathrm{cm}^{2}$ - diagonally on a plate. For each wavelength and energy density, three independent exposures were performed for three independent samples. The cells were incubated for $24 \mathrm{~h}$ under standard conditions (as above) and then subjected to laser irradiation (PBM).

\subsection{Cell Proliferation MTT Test}

The viability and proliferation of cells were determined by MTT test (Sigma-Aldrich) at 24,48 , and $72 \mathrm{~h}$ after laser irradiation. The method allows for determining cell survival by measuring the mitochondrial activity of the tested cells. After removal of the culture medium above cells, $100 \mu \mathrm{L}$ of MTT solution $(0.5 \mathrm{mg} / \mathrm{mL})$ was added to each well (including one well without cells that served as a blank control). Then, the plates were incubated for $2 \mathrm{~h}$ in the $\mathrm{CO}_{2}$ incubator. As a result of the reaction from the water-soluble MTT salt (tetrazole salt (3-(4,5-dimethylthiazol-2-yl)-2,5-diphenyltetrazolium bromide)) with succinate dehydrogenase, formazan, dark purple, insoluble crystals were formed. Further, crystals were dissolved by the addition of $100 \mu \mathrm{L}$ of acidic isopropanol to each well. The number of crystals formed was proportional to the amount of mitochondrial succinate dehydrogenase that is active in living cells. The absorbance of the colored solution was measured spectrophotometrically at $570 \mathrm{~nm}$, on a Multiskan ${ }^{\mathrm{TM}}$ FC microplate photometer (Thermo Scientific, Alab, Warsaw, Poland). Each tested parameter was performed in triplicate and repeated three times within the independent experiments.

\subsection{Statistical Analysis}

The statistical analysis was performed using Statistica version 13.3 (Stat Soft, Krakow, Poland). The normal distribution was confirmed using the Shapiro-Wilks test. The presence of statistical differences was determined based on the analysis of variance and the Turkey post hoc test, and the statistical significance level was 0.05 . The analysis of variance for multivariate classification was used to evaluate the effect of two controlled factors on the mitochondrial activity of cells (\% of MA) (dependent variable Y). The independent variables for each laser included: laser radiation dose (variable X1—surface energy density GE: $0,3,25$ and $64 \mathrm{~J} / \mathrm{cm}^{2}$ ) and the incubation time in the culture fluid (variable X2-three lengths: 24,48 and $72 \mathrm{~h}$ ) and their interactions.

\section{Results}

A decrease in the mitochondrial activity (\% of MA) below 100\% was observed in all groups $24 \mathrm{~h}$ after irradiation with the $405 \mathrm{~nm}$ laser $\left(3 \mathrm{~J} / \mathrm{cm}^{2}, 25 \mathrm{~J} / \mathrm{cm}^{2}, 64 \mathrm{~J} / \mathrm{cm}^{2}\right)$. A statistically significant difference in comparison to the control group was recorded for an energy density of $64 \mathrm{~J} / \mathrm{cm}^{2}$. Regardless of the energy density, the highest increase in the percentage of MA was observed $48 \mathrm{~h}$ after the exposure (MA $>115 \%)$; during this period, its statistical differences were shown in relation to the control group. The highest percentage of MA $(117.9 \%)$ was observed after $48 \mathrm{~h}$ at an energy density of $25 \mathrm{~J} / \mathrm{cm}^{2}$ (without statistically significant differences from other energy densities: $3 \mathrm{~J} / \mathrm{cm}^{2}$ and $64 \mathrm{~J} / \mathrm{cm}^{2}$ ). After $72 \mathrm{~h}$, the $\%$ of MA decreased again to a value not statistically different from the control group. The results for MA in this group are shown in Table 2 and Figure 1. The interaction between energy density and incubation time after irradiation for mitochondrial activity is shown in Figure 2a.

In case of the group treated with the $450 \mathrm{~nm}$ laser, a statistically significant decrease in the mitochondrial activity was observed $24 \mathrm{~h}$ after the exposure in the irradiated subgroup with an energy density of $3 \mathrm{~J} / \mathrm{cm}^{2}(85.6 \%)$ and $64 \mathrm{~J} / \mathrm{cm}^{2}(87.3 \%)$ compared to the control group. MA values for the $25 \mathrm{~J} / \mathrm{cm}^{2}$ subgroup did not differ statistically from the control group. After $48 \mathrm{~h}$ of exposure, it was observed that the energy density of 3,25 and $64 \mathrm{~J} / \mathrm{cm}^{2}$ led to an increase in the mitochondrial activity above $100 \%$ but without statistical differences 
compared to the control group. MA percentage measurements after $72 \mathrm{~h}$ did not show a statistically significant difference from the control group. The highest MA value was reached after $72 \mathrm{~h}$ in the group exposed to an energy density of $25 \mathrm{~J} / \mathrm{cm}^{2}$. The results for MA in this group are shown in Table 2 and Figure 3. The interaction between energy density and incubation time after irradiation for mitochondrial activity is shown in Figure $2 b$.

Table 2. Values of mitochondrial activity (MA) in function of wavelength, energy density (ED), and time (t) between irradiation and mitochondrial activity measurement (SE)—standard error, bold font- statistically significant difference versus control group, ref-control group).

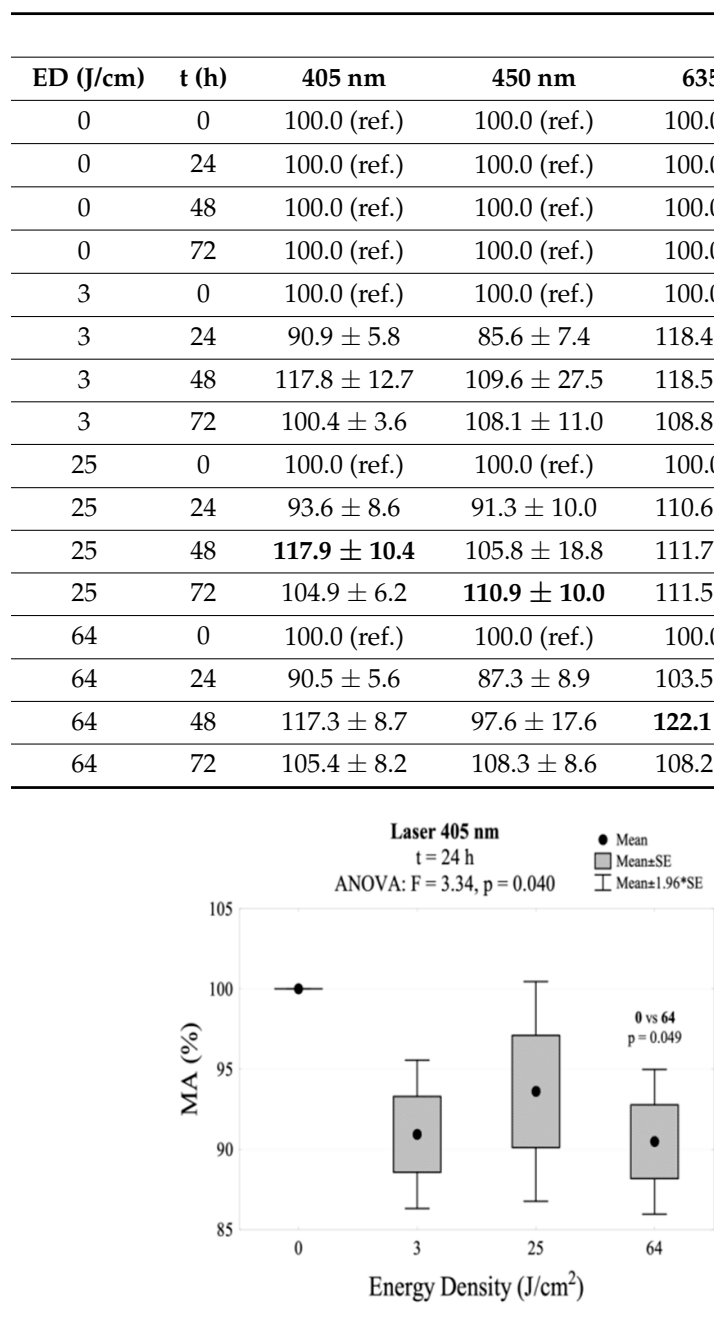

(a)

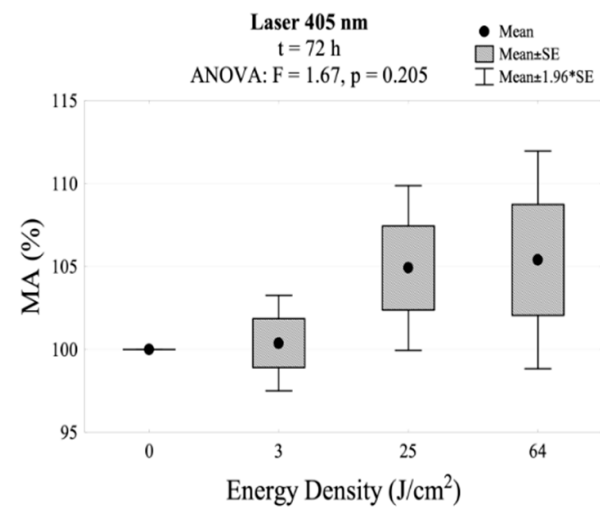

(c)

Figure 1. MA values measured (a) $24 \mathrm{~h}$, (b) $48 \mathrm{~h}$, and (c) $72 \mathrm{~h}$ after irradiation using the $405 \mathrm{~nm}$ laser. 


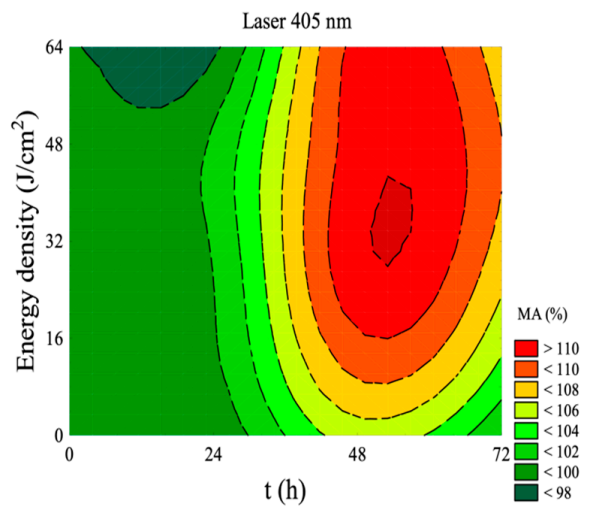

(a)

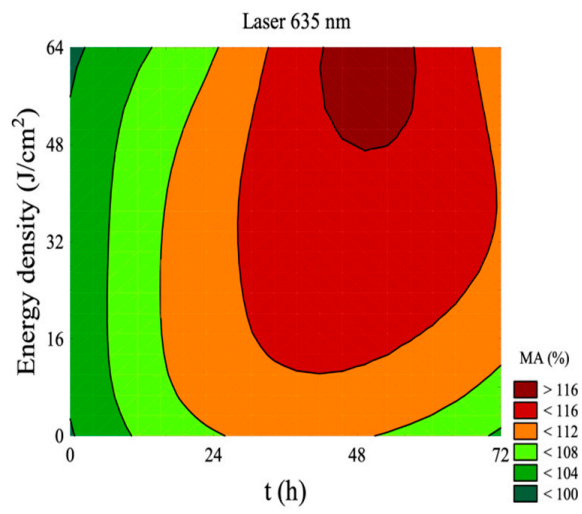

(c)

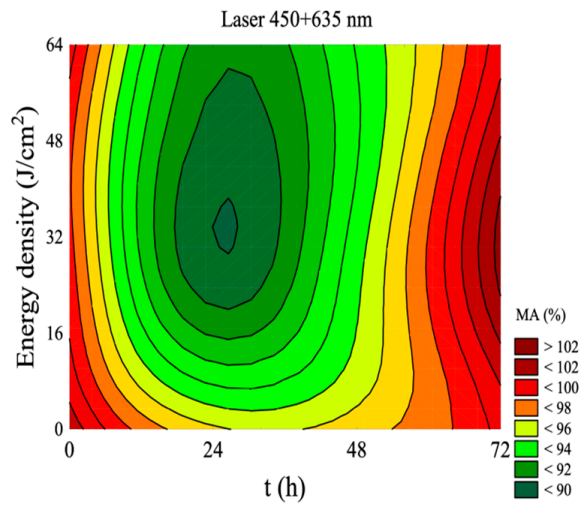

(e)

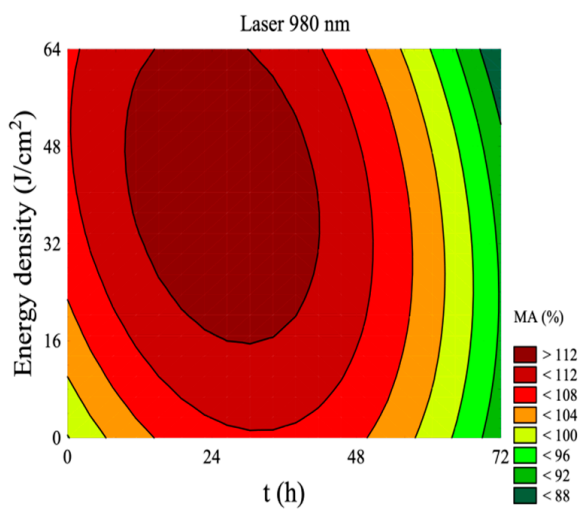

(g)

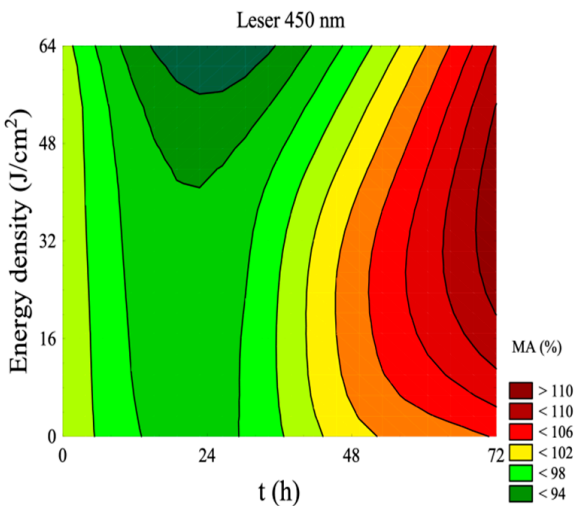

(b)

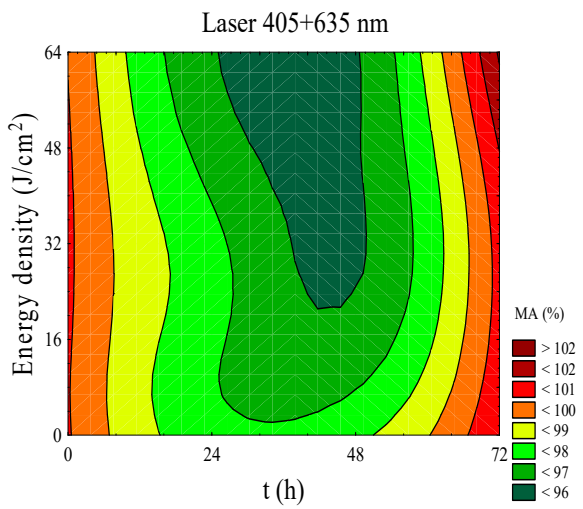

(d)

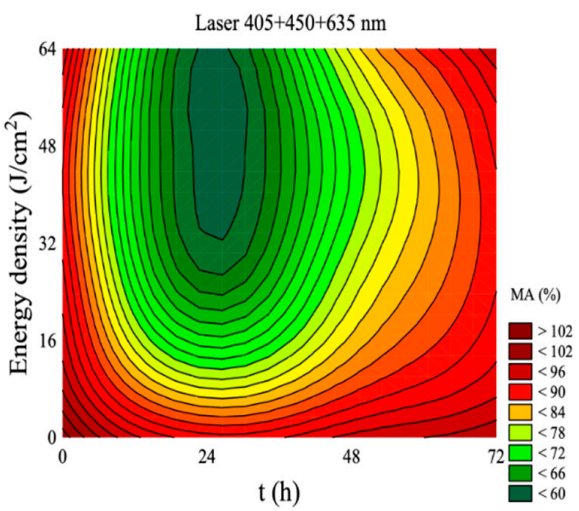

(f)

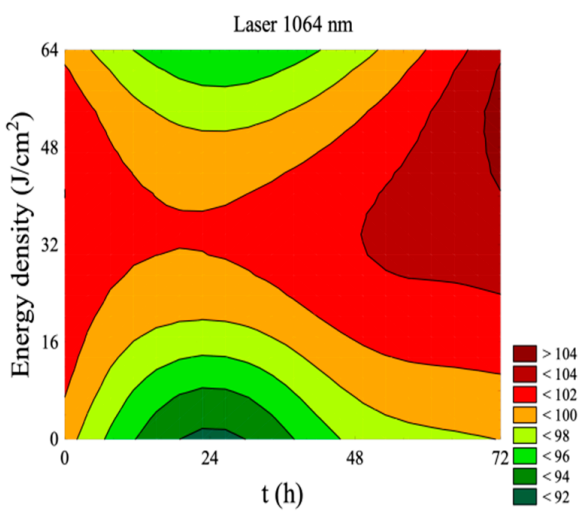

(h)

Figure 2. Interaction between energy density and time of incubation for mitochondrial activity after irradiation for: (a) $405 \mathrm{~nm}$, (b) $450 \mathrm{~nm}$, (c) $635 \mathrm{~nm}$, (d) $405+635 \mathrm{~nm}$, (e) $450+635 \mathrm{~nm}$, (f) $405+450+635 \mathrm{~nm}$, (g) $980 \mathrm{~nm}$, (h) $1064 \mathrm{~nm}$. 


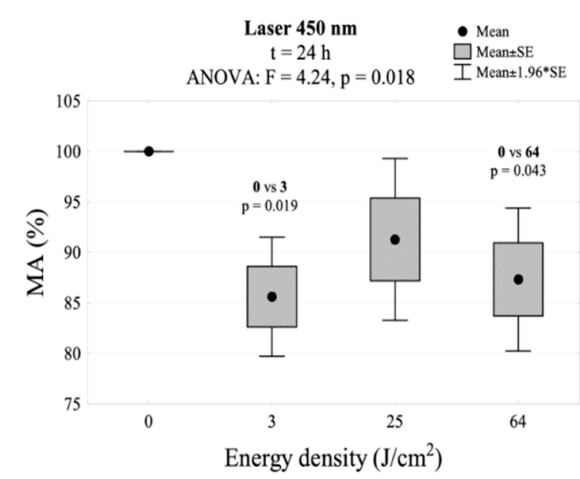

(a)

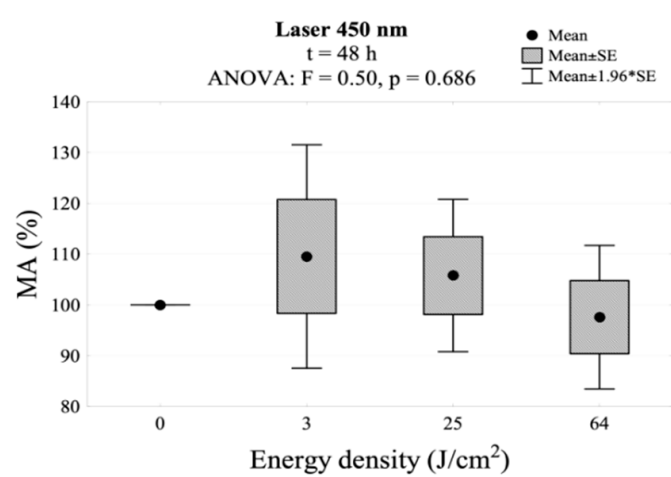

(b)

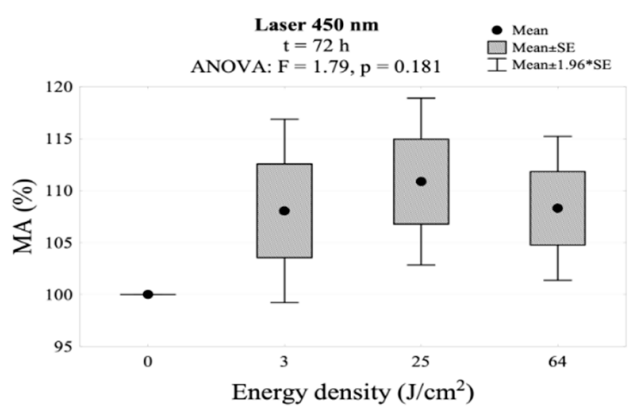

(c)

Figure 3. MA values measured (a) $24 \mathrm{~h}$, (b) $48 \mathrm{~h}$, and (c) $72 \mathrm{~h}$ after irradiation using the $450 \mathrm{~nm}$ laser.

In the group irradiated with the $635 \mathrm{~nm}$ laser, after $24 \mathrm{~h}$ there was an increase in the MA for all energy densities $\left(3 \mathrm{~J} / \mathrm{cm}^{2}, 25 \mathrm{~J} / \mathrm{cm}^{2}, 64 \mathrm{~J} / \mathrm{cm}^{2}\right)$, but without statistically significant differences in relation to the control group. After $48 \mathrm{~h}$, the mitochondrial activity reached the highest value for an energy density of $64 \mathrm{~J} / \mathrm{cm}^{2}(122.1 \%)$. This measurement showed statistical differences from the control group. A decrease in the MA was observed $72 \mathrm{~h}$ after the exposure for all energy densities. The results for MA in this group are shown in Table 2 and Figure 4. The interaction between energy density and incubation time after irradiation for mitochondrial activity is shown in Figure 2c.

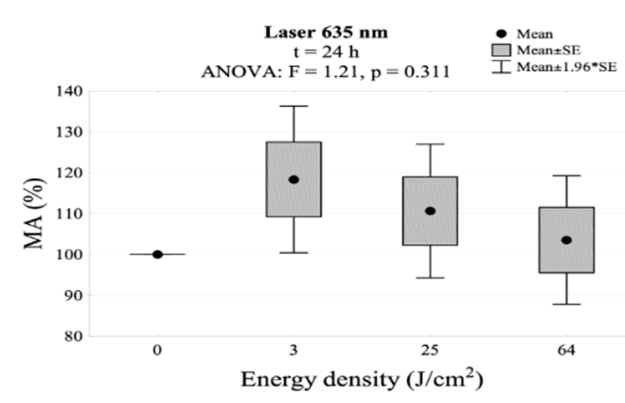

(a)

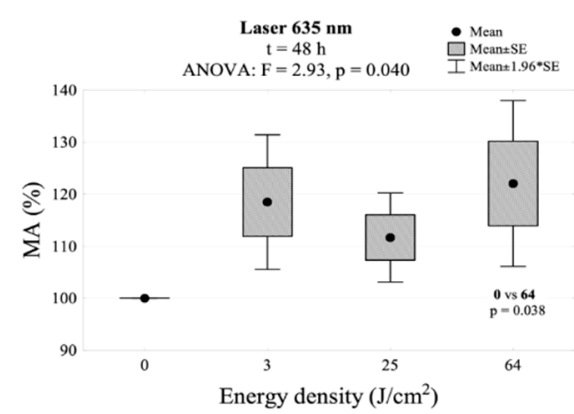

(b)

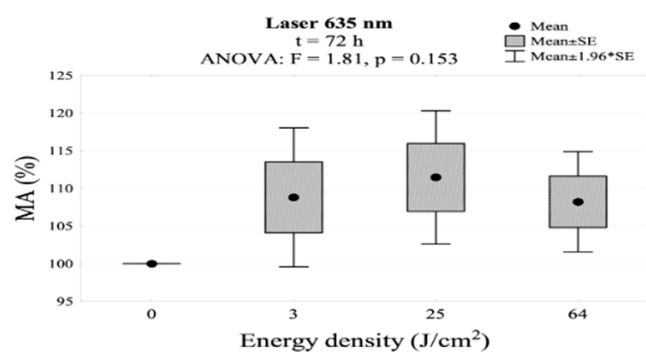

(c)

Figure 4. MA values measured (a) $24 \mathrm{~h}$, (b) $48 \mathrm{~h}$, and (c) $72 \mathrm{~h}$ after irradiation using the $635 \mathrm{~nm}$ laser. 
In the group simultaneously irradiated with two wavelengths $(405+635 \mathrm{~nm}), 24$ and $48 \mathrm{~h}$ after the exposure, the MA dropped below $100 \%$ without statistical differences compared to the control group. A slight increase in the mitochondrial activity was observed $72 \mathrm{~h}$ after the exposure without statistically significant differences in comparison to the control group. After this period, the highest MA value (102.5\%) was also observed in the irradiated group with an energy density of $64 \mathrm{~J} / \mathrm{cm}^{2}$. The results showing MA values with simultaneous irradiation with two wavelengths $(405+635 \mathrm{~nm})$ are presented in Table 2 and Figure 5. The interaction between energy density and incubation time after irradiation for mitochondrial activity is shown in Figure 2d.

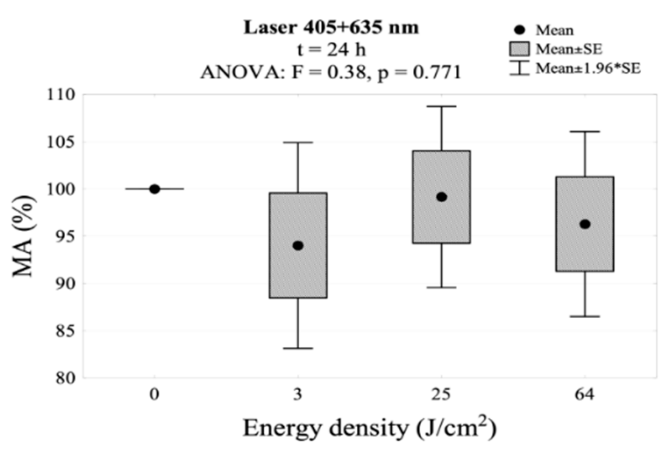

(a)

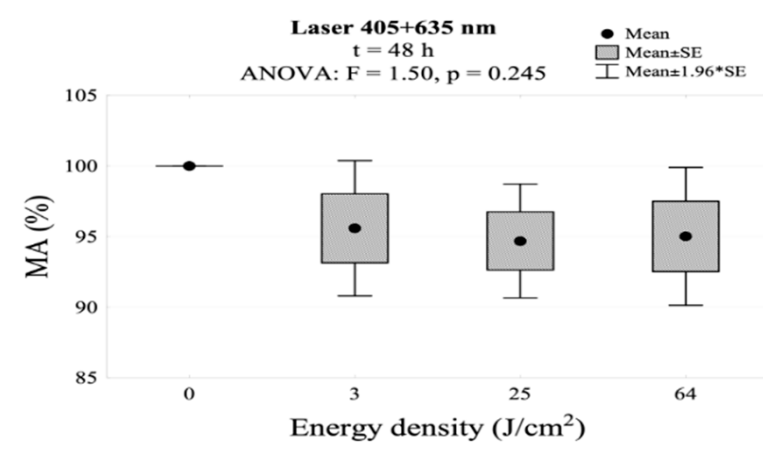

(b)

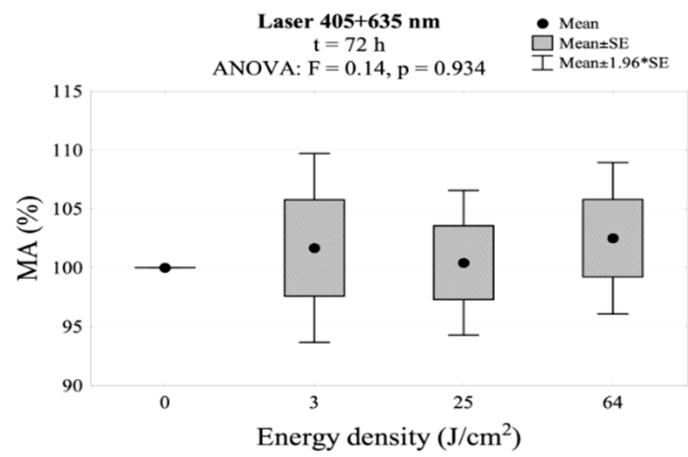

(c)

Figure 5. MA measured (a) $24 \mathrm{~h},($ b) $48 \mathrm{~h}$, and (c) $72 \mathrm{~h}$ after irradiation using the $405+635 \mathrm{~nm}$ laser.

In the group simultaneously irradiated with two wavelengths $(450+635 \mathrm{~nm})$, after 24 and $48 \mathrm{~h}$ for all energy densities, a decrease in MA below 100\% was noted, without a statistical difference compared to the control group. It seems interesting that despite the initial decrease in the MA value, it slightly increased to $103.8 \%$ after $72 \mathrm{~h}$ in the group irradiated with an energy density of $25 \mathrm{~J} / \mathrm{cm}^{2}$. However, this difference was not statistically significant. The results regarding the MA value using two wavelengths $(450+635 \mathrm{~nm})$ are presented in Table 2 and Figure 6. The interaction between energy density and time of incubation after irradiation for mitochondrial activity is shown in Figure 2e.

The simultaneous irradiation with three wavelengths $(405+450+635 \mathrm{~nm})$ resulted in a significant decrease below 100\% in MA activity after $24 \mathrm{~h}$. This decrease was observed for all energy densities and was statistically significant in relation to the control group. The largest decrease was observed in the group irradiated with energy density of 25 and $64 \mathrm{~J} / \mathrm{cm}^{2}$. In both groups, the MA dropped below 50\%. After $48 \mathrm{~h}$, there was an increase in mitochondrial activity to the level of the control group when exposed to an energy density of 3 and $64 \mathrm{~J} / \mathrm{cm}^{2}$. When exposed to an energy density of $25 \mathrm{~J} / \mathrm{cm}^{2}$, the MA value still showed a statistical difference from the control. After $72 \mathrm{~h}$, the 25 and $64 \mathrm{~J} / \mathrm{cm}^{2}$ groups showed no change as opposed to the next MA decrease in the $3 \mathrm{~J} / \mathrm{cm}^{2}$ group. This decrease was a statistically significant compared to the control group. The results of MA 
relation to the use of three wavelengths $(405+450+635 \mathrm{~nm})$ are shown in Table 2 and Figure 7 . The interaction between energy density and time of incubation after irradiation for mitochondrial activity is shown in Figure $2 \mathrm{f}$.

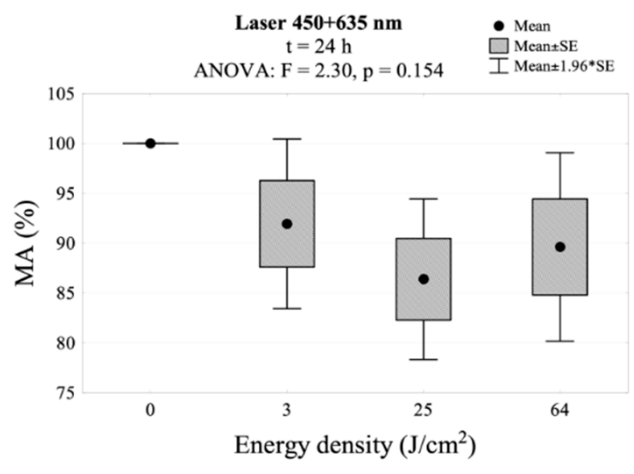

(a)

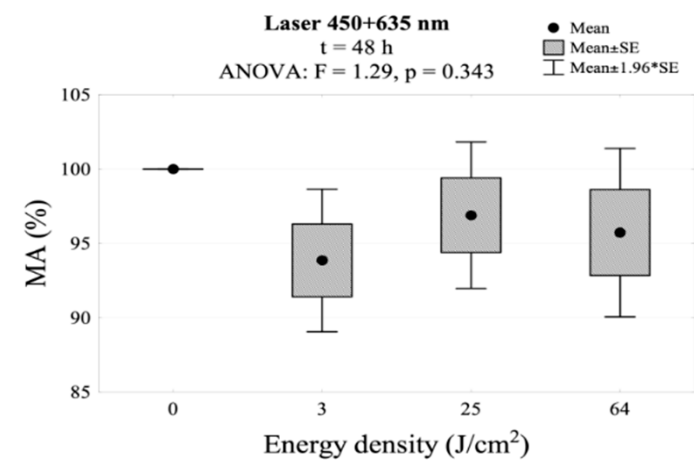

(b)

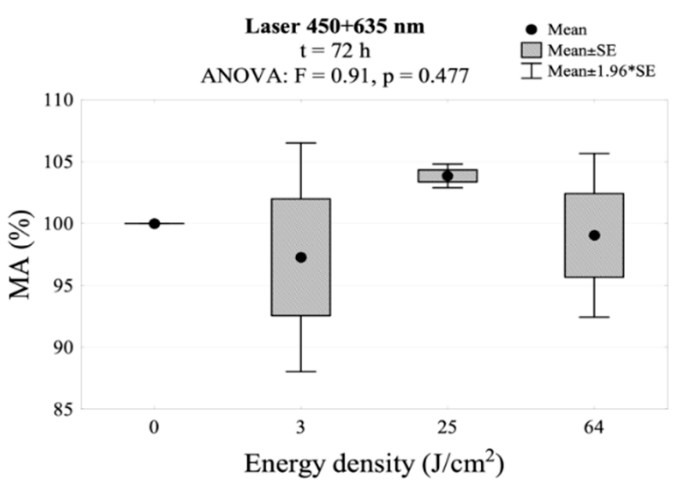

(c)

Figure 6. MA values measured: (a) $24 \mathrm{~h}$, (b) $48 \mathrm{~h}$, (c) $72 \mathrm{~h}$. after irradiation using the $450+635 \mathrm{~nm}$ laser.

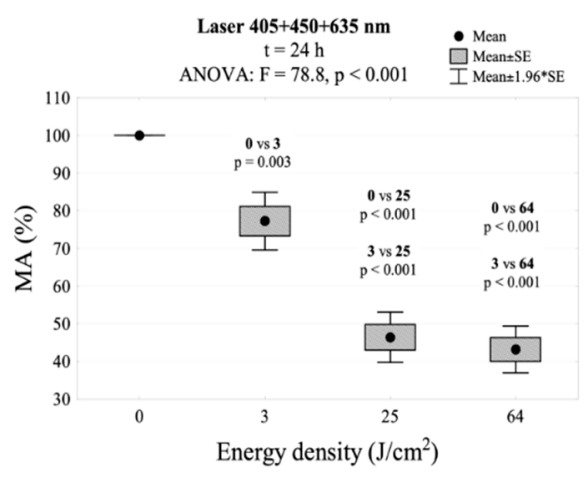

(a)

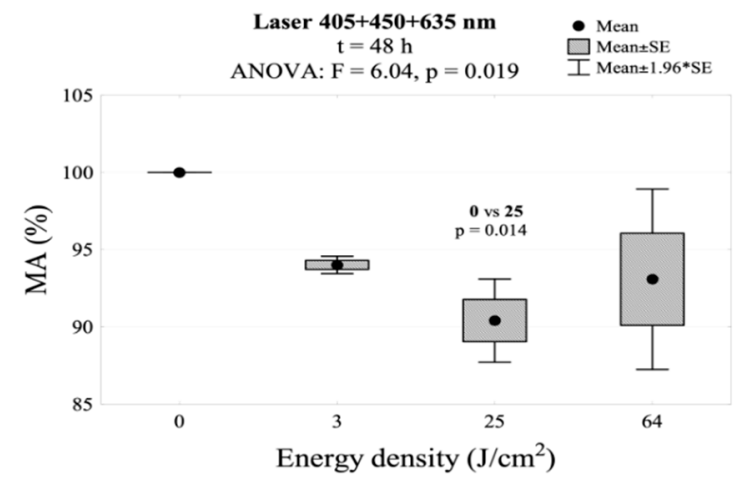

(b)

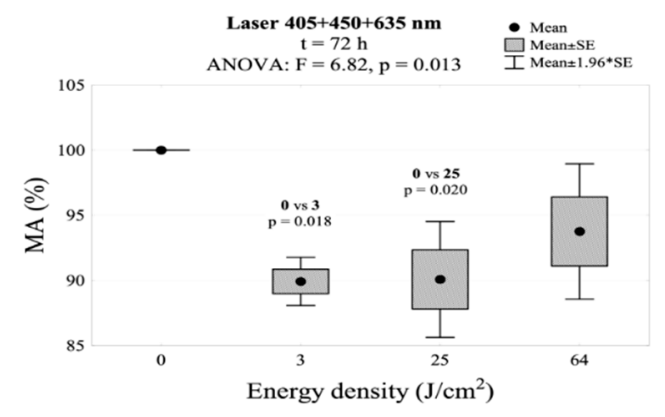

(c)

Figure 7. MA values measured: (a) $24 \mathrm{~h}$, (b) $48 \mathrm{~h}$, (c) $72 \mathrm{~h}$ after irradiation using the $405+450+635 \mathrm{~nm}$ laser. 
After $24 \mathrm{~h}$ of irradiation with the $980 \mathrm{~nm}$ laser, an increase in MA activity was noted. At an energy density of $25 \mathrm{~J} / \mathrm{cm}^{2}$, this increase was the highest (126.6\%). However, it has not been shown that this increase was statistically significant compared to the control group. After $48 \mathrm{~h}$ of the exposure to all energy densities, a decrease in the MA value was noted (without statistically significant differences in relation to the control group). After $72 \mathrm{~h}$, this decrease would deepen at all energy densities, reaching levels below 100\% (without statistical differences compared to the control group). The results of MA relation to the use of the $980 \mathrm{~nm}$ laser irradiation are presented in Table 2 and Figure 8. The interaction between energy density and time of incubation after irradiation for mitochondrial activity is shown in Figure $2 \mathrm{~g}$.

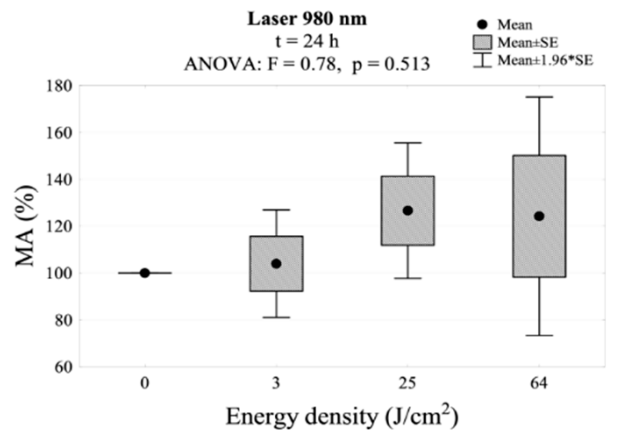

(a)

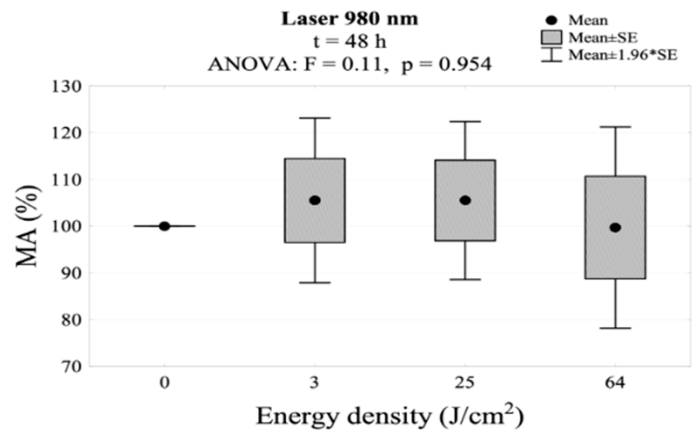

(b)

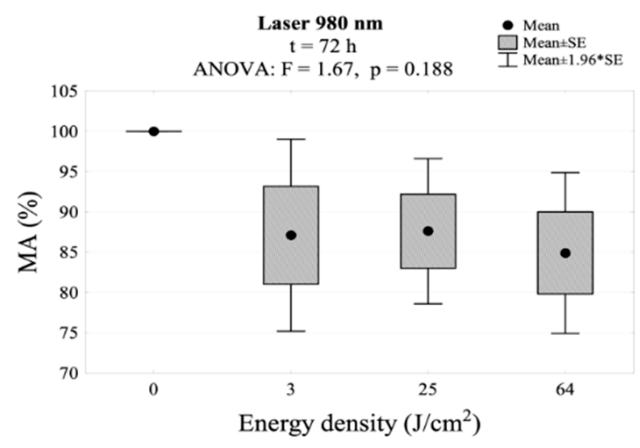

(c)

Figure 8. MA values measured: (a) $24 \mathrm{~h}$, (b) $48 \mathrm{~h}$, (c) $72 \mathrm{~h}$ after irradiation using the $980 \mathrm{~nm}$ laser.

After $24 \mathrm{~h}$ of the exposure, with the $1064 \mathrm{~nm}$ laser, the $3 \mathrm{~J} / \mathrm{cm}^{2}$ energy density group showed a statistically significant decrease in relation to the control group. After the irradiation with an energy density of 25 and $64 \mathrm{~J} / \mathrm{cm}^{2}$, there were no statistically significant differences in the MA value in relation to the control group. After $48 \mathrm{~h}$, there was an increase in MA activity with $3 \mathrm{~J} / \mathrm{cm}^{2}$ irradiation compared to the control group level. The groups with 25 and $64 \mathrm{~J} / \mathrm{cm}^{2}$ did not differ statistically from the controls after 48 and $72 \mathrm{~h}$. The highest MA value (104.0\%) was obtained after $72 \mathrm{~h}$ at $64 \mathrm{~J} / \mathrm{cm}^{2}$ energy density. The MA values for $1064 \mathrm{~nm}$ laser irradiation are shown in Table 2 and Figure 9. The interaction between energy density and time of incubation after irradiation for mitochondrial activity is shown in Figure $2 \mathrm{~g}$.

To sum up, the highest percentage of MA (122.1\%) was observed in the group irradiated with the $635 \mathrm{~nm}$ laser, at an energy density of $64 \mathrm{~J} / \mathrm{cm}^{2}$, after $48 \mathrm{~h}$. The lowest percentage of MA $(94.0 \%)$ was recorded in the group simultaneously irradiated with three wavelengths $(405+460+635 \mathrm{~nm})$. Noteworthy, the use of the $405 \mathrm{~nm}$ laser gave similar results to the $635 \mathrm{~nm}$ laser, although at a lower energy density of only $25 \mathrm{~J} / \mathrm{cm}^{2}$. It is also important to observe that the standard deviation (SD) reached the highest value (SD $= \pm 71.7$ ) in the case of $980 \mathrm{~nm}$ laser irradiation (after $24 \mathrm{~h}$ and at an energy density of $25 \mathrm{~J} / \mathrm{cm}^{2}$ ) and 
$48 \mathrm{~h}$ after $635 \mathrm{~nm}$ laser irradiation at an energy density of $64 \mathrm{~J} / \mathrm{cm}^{2}(\mathrm{SD}= \pm 34.5)$. In other cases, the SD did not exceed $11.1 \%$ (Table 3).

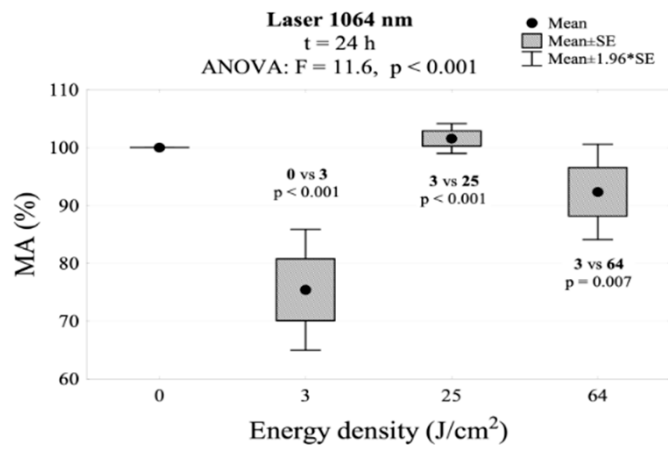

(a)

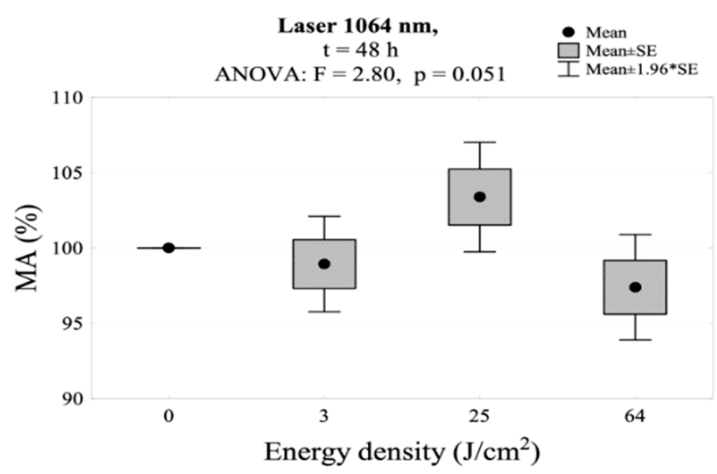

(b)

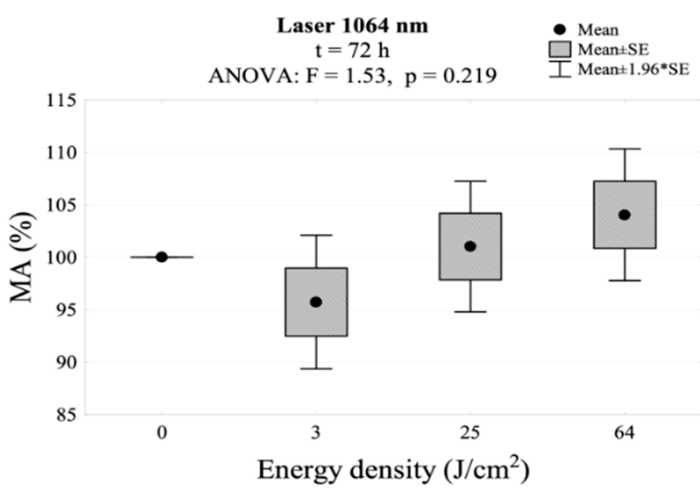

(c)

Figure 9. MA values measured: (a) $24 \mathrm{~h}$, (b) $48 \mathrm{~h}$, (c) $72 \mathrm{~h}$ after irradiation using the $1064 \mathrm{~nm}$ laser.

Table 3. Maximum values of mitochondrial activity $\left(\mathrm{MA}^{\max }\right)$ for various wavelengths $(\lambda)$, amounts of time after irradiation (t) and energy densities (ED) (SD-standard deviation).

\begin{tabular}{ccccccccc}
\hline \multirow{2}{*}{ MA $^{\text {max }}(\mathbf{9})$} & \multicolumn{8}{c}{ Laser } \\
\cline { 2 - 10 } & A & B & C & D & E & F & G & H \\
\hline$\lambda(\mathrm{nm})$ & 405 & 450 & 635 & $405+635$ & $450+635$ & $405+450+635$ & 980 & 1064 \\
\hline $\mathrm{ED}\left(\mathrm{J} / \mathrm{cm}^{2}\right)$ & 25 & 25 & 64 & 64 & 25 & 3 & 25 & 64 \\
\hline $\mathrm{t}(\mathrm{h})$ & 48 & 72 & 48 & 72 & 72 & 48 & 24 & 72 \\
\hline Mean $\pm \mathrm{SD}$ & $117.9 \pm 10.4$ & $110.9 \pm 10.0$ & $122.1 \pm 34.5$ & $102.5 \pm 8.0$ & $103.8 \pm 0.8$ & $94.0 \pm 0.5$ & $126.6 \pm 71.7$ & $104.0 \pm 11.1$ \\
\hline
\end{tabular}

\section{Discussion}

As the main connective tissue cells, fibroblasts are responsible for the formation of the extracellular matrix and collagen. In the case of chronic stimuli leading to connective tissue damage, cell signaling and angiogenesis are disturbed and delayed [36].

When dealing with a deficit of the connective tissue, it seems important to supplement fibroblasts by implanting or, in the case of small defects, stimulating cells to migrate from the periphery of the wound. Yu et al. found a directly proportional relationship between the amount of fibroblast growth factor (FGF) and proliferating cells regenerating the gingivaacellular cementum junction [37]. It has been demonstrated that the proliferation and migration of fibroblasts can be enhanced with the use of photobiomodulation, PBM. A wide spectrum of physical parameters that stimulate PBM, such as the light wavelength, power, exposure time, energy dose, frequency and type of laser, are administered [24,38]. However, there is no statement as to which wavelength, at what energy density, will 
result in the largest amount of fibroblasts. According to Sajan et al., it is the wavelength, not energy density, that affects oxidative stress and ATP levels, and thus also cellular proliferation [39]. Others think that energy density plays an important role.

Our experimental study was conducted in vitro. Fibroblasts were photobiomodulated in an optically transparent culture medium, in which cells should theoretically proliferate best at wavelengths of 400-600 nm. However, in vivo, cells should preferably proliferate at wavelengths of 600-1200 nm, due to the optical properties of the tissues [22,40-42]. This explains the use of so many different wavelengths.

According to Chung et al., red/near infrared (NIR) light seems to be the most desirable for PBM effects due to its smaller dispersion. It is absorbed by tissue chromophores and therefore maximally penetrates the tissue, affecting cell proliferation and migration [43]. Ravera et al. observed the interaction of the $1064 \mathrm{~nm} \mathrm{Nd:} \mathrm{YAG} \mathrm{laser} \mathrm{on} \mathrm{mitochondrial}$ aerobic metabolism and complex activity as well as ATP production [24].

The results of our pilot study, in the case of the group irradiated with the $635 \mathrm{~nm}$ laser, showed an increase in the mitochondrial activity in relation to the control group for all energy densities, after 24 and $48 \mathrm{~h}$, which is of great importance in terms of the prevention of soft tissue scarring. Both the wavelengths of red and near infrared spectrum penetrate very well through the mucosa [16]. Therapy with these wavelengths decreases the level of IL-6 cytokine mRNA, which is responsible for scarring processes, so detrimental to the aesthetic effect $[23,44,45]$. Using a wavelength of $635 \mathrm{~nm}$ at $3 \mathrm{~J} / \mathrm{cm}^{2}$ at a distance of $3 \mathrm{~cm}$ from the sample, Huang et al. found that by activating the Copper-glycyl-L-histidyl-L-lysin complex (Cu-GHK), red light increases the main secretion fibroblast growth factor, i.e., basic fibroblast growth factor (bFGF), and the production of procolagen 1 carboxyterminal propeptide (P1CP 9) which directly accelerates the wound healing process through its anti-inflammatory effects [46]. Cannarozzo et al. confirmed that $675 \mathrm{~nm}$ wavelength is useful to treatment of scars [47]. A statistically significant increase in fibroblast proliferation with red light was noted by most researchers at an energy density under $15 \mathrm{~J} / \mathrm{cm}^{2}$. Sajan et al. found that the use of a wavelength of $636 \mathrm{~nm}$ at $25 \mathrm{~J} / \mathrm{cm}^{2}$ reduces oxidative stress, which is important in modulating the proliferation and migration of fibroblasts and wound healing [39]. At the same time, both Sajan and Khan observed that the use of doses of over $15 \mathrm{~J} / \mathrm{cm}^{2}$ in the case of the NIR laser has a phototoxic effect on cells. The increase in temperature activates, inter alia, heat shock protein 70 (HSP70)), generating harmful reactive oxygen species (ROS), damaging the functioning of the mitochondria $[39,48]$. Our study showed a statistically significant increase in the $64 \mathrm{~J} / \mathrm{cm}^{2}$ group after $48 \mathrm{~h}$.

The advantage of low -power lasers over high-power lasers is that they cause lower thermal effects, which, combined with the lack of production of highly reactive oxygen species, do not damage cell membranes or DNA [49]. Our research shows that irradiation with a diode laser, with a wavelength of $980 \mathrm{~nm}$ for a power of 1-2 W, energy density of 3, 25 and $64 \mathrm{~J} / \mathrm{cm}^{2}$ (PW) and duration of 3,25 and $32 \mathrm{~s}$ does not have a significant effect on the biostimulation of fibroblasts, but it also does not cause cell apoptosis. Furthermore, an increase in the mitochondrial activity (MA) was observed after $24 \mathrm{~h}$ at all energy densities $\left(3,25\right.$ and $\left.64 \mathrm{~J} / \mathrm{cm}^{2}\right)$. The highest MA increase was observed in the group treated with the energy density of $25 \mathrm{~J} / \mathrm{cm}^{2}$. However, at 48 and $72 \mathrm{~h}$, there was a decrease in cell proliferation in all three energy groups. This could be the result of increased expression of alpha-actin, a marker that differentiates fibroblasts into myofibroblasts [50,51]. A decrease in MA after 48 and $72 \mathrm{~h}$ was also observed by Kreisler et al. The authors emphasized the need for repeated irradiation of the treatment site every $24 \mathrm{~h}$ in clinical settings [52]. Similarly, in an in vivo study, Illescas-Montes et al. used a $940 \mathrm{~nm}$ diode laser at $0.5 \mathrm{~W}$ and $4 \mathrm{~J} / \mathrm{cm}^{2}$ in two doses after 24 and $72 \mathrm{~h}$. They observed a decrease in elastin expression, which has a positive effect on the regeneration of keratinized gingiva without leaving hypertrophic scars or keloids [53]. Our results correspond to the Engel's report, stating that infrared spectrum exposure is more effective when using low power at high dose levels [54]. Gkogkos et al. proved that the use of high doses of energy at low power promotes fibroblast proliferation $48 \mathrm{~h}$ after irradiation, which in turn can induce the 
secretion of growth factors [55]. The use of the Nd:YAG laser with a power of $0.5-1.0 \mathrm{~W}$ at a density of 25 and $64 \mathrm{~J} / \mathrm{cm}^{2}$ in impulse mode, at a distance of $5 \mathrm{~mm}$ from the cells did not cause fibroblast apoptosis but their proliferation, although the result was statistically insignificant. Most studies assessing cell proliferation and PBM effects in the infrared range involve diode lasers. Gkogkos et al., in the studies on the effectiveness of the Nd:YAG laser, observed a statistically significant increase in fibroblast proliferation in the group with the highest density used in the study, i.e., $15.8 \mathrm{~J} / \mathrm{cm}^{2}$ using $0.5 \mathrm{~W}$ power after $48 \mathrm{~h}$. The authors recommended the use of higher energy densities with less power [55]. Gutknecht et al. observed thermal cell damage and necrosis after Nd:YAG laser irradiation using a power of 2.1-3.0 W at a distance of $2 \mathrm{~mm}$ from the sample. They considered the exposure time to be $30 \mathrm{~s}$ or more as the reason [56]. Similarly, Almeida-Lopes et al. compared the efficacy of different wavelengths and they found that the infrared laser promoted gingival fibroblast proliferation with shorter cell exposure [57]. Our study did not confirm this theory. Sağlam et al. used Nd:YAG irradiation at a wavelength of $1064 \mathrm{~nm} 1.5-2.0 \mathrm{~W}$, with exposure time of 10-20 s, at a distance of $2 \mathrm{~mm}$ from the sample. Neither cell apoptosis nor an increased release of growth factors was observed. A significant increase in the release of VEGF within $24 \mathrm{~h}$ was observed only in the group using the parameters of $2 \mathrm{~W}$ and the exposure time of $20 \mathrm{~s}$ [58].

Chen et al. noted the apoptosis of human fibroblasts in the gingiva induced by Nd:YAG laser radiation after the application of the power of 1.0-3.0 W and in direct contact with the cells. However, after irradiation of the cells from a distance of $2 \mathrm{~mm}$, no significant decrease in fibroblasts viability was observed [59]. Therefore, comparing two types of light-red and near infrared, which should best stimulate fibroblasts to proliferate clinically, a statistically significant increase in MA in relation to the control group was recorded for the $635 \mathrm{~nm}$ laser.

Our research also assessed the stimulation of fibroblasts in the field of violet and blue light by means of a diode laser prototype constructed for the project. In this study, a statistically significant increase in MA after $48 \mathrm{~h}$ of irradiation with a $405 \mathrm{~nm}$ wavelength was observed for all energy densities of 3,25 and $64 \mathrm{~J} / \mathrm{cm}^{2}$. Importantly, it was comparable in each case. Among the categories of violet light, the range of approx $400 \mathrm{~nm}$ is the safest as it is not absorbed by any of the DNA bases. Simultaneously, wavelengths close to $400 \mathrm{~nm}$ can generate reactive oxygen species (ROS) at low doses, which are associated with the effects of PBM and do not damage DNA. Similarly, blue light has a stimulating effect on ROS production, although only in high doses [60-62].

It has an inhibitory effect on the proliferation, not only of cancer cells, but also of fibroblasts, as shown in our pilot study. There are reports in the literature of blue light stimulating fibroblast proliferation in vivo and in vitro. The observations included the direct contact of the laser tip with the keratinized gingival, due to the shallow penetration of this wavelength. In our study, the laser tip was at a $5.0 \mathrm{~mm}$ distance from the samples, as was the case with our other research groups. Therefore, it might be seen as the reason of the result of our study [63-65].

One of the aims of this pilot study was also to assess fibroblasts proliferation after using laser irradiation, with a beam composed of different wavelengths. Trelles et al. described in clinical studies the effects of a laser equipped with replaceable tips based on LEDs emitting light in the red and near infrared range. They used two wavelengths in the correct order: $830 \pm 5 \mathrm{~nm}$ (near infrared) and $633 \pm 3 \mathrm{~nm}$ (visible red), taking advantage of the fact that red light is focused on fibroblasts, and near infrared light is associated with the PBM of cells, which affects wound healing, and the transformation of fibroblasts into myofibroblasts. Both wavelengths increased the local blood supply. The combination was found to be more effective than using one of the wavelengths [66]. We did not find any research linking the same wavelengths as in our study in the literature. In our study, none of the combinations of different wavelengths in a pulse mode resulted in the expected statistically significant fibroblast proliferation. However, when combining the 405 and $635 \mathrm{~nm}$ wavelengths, no apoptosis was observed. On the other hand, proliferation similar to the control group was 
observed in the $64 \mathrm{~J} / \mathrm{cm}^{2}$ group, after $72 \mathrm{~h}$ of incubation. The results were similar in the case of combining the 450 and $635 \mathrm{~nm}$ wavelengths, but proliferation was observed in the $25 \mathrm{~J} / \mathrm{cm}^{2}$ group also after $72 \mathrm{~h}$ of incubation. In contrast, statistically significant cell apoptosis was observed in a group combining the 405,450 , and $635 \mathrm{~nm}$ wavelengths.

\section{Conclusions}

When using a $405 \mathrm{~nm}$ laser, a decrease in MA activity below 100\% was observed on the first day after the exposure. A sudden, statistically significant increase in relation to the control group occurred after $48 \mathrm{~h}$ for energy densities of 3, 25, and $64 \mathrm{~J} / \mathrm{cm}^{2}$. It is important that this increase was comparable for all energy densities.

In the case of the $635 \mathrm{~nm}$ and $980 \mathrm{~nm}$ lasers, an increase in mitochondrial activity was noted as early as on the first day after irradiation, but without statistically significant differences in relation to the control group.

The use of a $635 \mathrm{~nm}$ laser at the energy density of $64 \mathrm{~J} / \mathrm{cm}^{2}$ resulted in the largest statistically significant increase in MA after $48 \mathrm{~h}$ in relation to the control group.

The initial decrease in the MA value after $24 \mathrm{~h}$ without statistical differences compared to the control, was observed in the groups irradiated with the 405, 450, $405+635,450+635$, and $1064 \mathrm{~nm}$ lasers. Statistically confirmed drop in MA after $24 \mathrm{~h}$ occurred when using the $405 \mathrm{~nm}$ laser (at $64 \mathrm{~J} / \mathrm{cm}^{2}$ energy density), the $1064 \mathrm{~nm}$ laser $\left(3 \mathrm{~J} / \mathrm{cm}^{2}\right.$ density) and the $405+450+635 \mathrm{~nm}$ lasers (for all energy densities).

The use of a $980 \mathrm{~nm}$ laser resulted in the highest MA value but without a statistical difference compared to the control group. Measurements of the MA activity in this group were burdened with the highest standard error.

The simultaneous use of three wavelengths $(405+450+635 \mathrm{~nm})$ caused a significant decrease in the MA value after $24 \mathrm{~h}$.

Our study suggested that of all the lasers used the $635 \mathrm{~nm}$ and $405 \mathrm{~nm}$ prototype visible laser (developed at the Polish Academy of Sciences) which caused a statistically significant increase in the proliferation of gingival fibroblasts. Clinically, this laser can be useful in periodontological plastic surgery in terms of obtaining an optimal amount of fibroblasts for the regeneration of soft tissue. Deficiency of keratinized gingiva is a common clinical problem in case of orthodontic, prosthetic or implantology treatment, so soft tissue irradiation in band 635 and $405 \mathrm{~nm}$ may accelerate the healing process.

Author Contributions: Conceptualization, K.G.-L., K.J., B.S. and W.T.; methodology, B.S., O.M., K.J., K.G.-L.; investigation, B.S. and K.J.; writing—original draft preparation, B.S.; writing-review and editing, K.J., B.S., O.M., K.G.-L., M.D.; supervision, W.T., M.D.; critical review M.D. All authors have read and agreed to the published version of the manuscript.

Funding: Wroclaw Medical University, Poland; statutory activity: ST.B040.17002, NCBR (National Center for Research and Development in Poland), grant PBS3/A7/18/2015 "LASDER".

Institutional Review Board Statement: Ethics Committee of Wroclaw Medical University, Poland (No KB-434/2017).

Informed Consent Statement: Informed consent was obtained from all subjects involved in the study.

Data Availability Statement: The authors got acquainted with MDPI Research Data Policies. The data that support the findings of this study are available from the corresponding author upon reasonable request.

Conflicts of Interest: The authors declare no conflict of interest. 


\section{References}

1. Luke, A.; Mathew, S.; Altawash, M.M.; Madan, B.M. Lasers: A Review with Their Applications in Oral Medicine. J. Lasers Med. Sci. 2019, 10, 324-329. [CrossRef]

2. Marques, E.C.P.; Lopes, F.P.; Nascimento, I.C.; Morelli, J.; Pereira, M.V.; Meiken, V.M.M.; Pinheiro, S.L. Photobiomodulation and photodynamic therapy for the treatment of oral mucositis in patients with cancer. Photodiagnosis Photodyn. Ther. 2020, $29,101621$. [CrossRef]

3. Jahanbin, A.; Eslami, N.; Layegh, P.; Saeidi, M.; Kazemi, M.; Shahabi, M.; Raisolsadat, S.M.A. Fractional CO(2) laser treat-ment for post-surgical lip scars in cleft lip and palate patients. Lasers Med. Sci. 2019, 34, 1699-1703. [CrossRef]

4. Chen, Y.; Chen, X.L.; Zou, X.L.; Chen, S.Z.; Zou, J.; Wang, Y. Efficacy of low-level laser therapy in pain management after root canal treatment or retreatment: A systematic review. Lasers Med. Sci. 2019, 34, 1305-1316. [CrossRef]

5. $\quad$ Escudero, J.S.B.; Perez, M.G.B.; de Oliveira Rosso, M.P.; Buchaim, D.V.; Pomini, K.T.; Campos, L.M.G.; Audi, M.; Buchaim, R.L. Photobiomodulation therapy (PBMT) in bone repair: A systematic review. Injury 2019, 50, 1853-1867. [CrossRef]

6. Ivonyak, Y.; Piechal, B.; Mrozowicz, M.; Bercha, A.; Trzeciakowski, W. Note: Coupling of multiple laser diodes into a multi-mode fiber. Rev. Sci. Instrum. 2014, 85, 36106. [CrossRef] [PubMed]

7. Lione, R.; Pavoni, C.; Noviello, A.; Clementini, M.; Danesi, C.; Cozza, P. Conventional versus laser gingivectomy in the management of gingival enlargement during orthodontic treatment: A randomized controlled trial. Eur. J. Orthod. 2019, 27, 78-85. [CrossRef] [PubMed]

8. Magri, L.V.; Bataglion, C.; Leite-Panissi, C.R. Follow-up results of a randomized clinical trial for low-level laser therapy in painful TMD of muscular origins. CRANIO 2019, 4, 1-8. [CrossRef]

9. Matys, J.; Swider, K.; Grzech-Lesniak, K.; Dominiak, M.; Romeo, U. Photobiomodulation by a 635 nm Diode Laser on Peri-Implant Bone: Primary and Secondary Stability and Bone Density Analysis. A Randomized Clinical Trial. Biomed. Res. Int. 2019, 2019, 2785302.

10. Neruntarat, C.; Khuancharee, K.; Shoowit, P. Er:YAG laser for snoring: A systemic review and meta-analysis. Lasers Med. Sci. 2020, 35, 1231-1238. [CrossRef]

11. Deeb, J.G.; Smith, J.; Belvin, B.R.; Lewis, J.P.; Grzech-Leśniak, K. Er:YAG Laser Irradiation Reduces Microbial Viability When Used in Combination with Irrigation with Sodium Hypochlorite, Chlorhexidine, and Hydrogen Peroxide. Microorganisms 2019, 7, 612. [CrossRef]

12. Grzech-Leśniak, K.; Gaspirc, B.; Sculean, A. Clinical and microbiological effects of multiple applications of antibacterial photodynamic therapy in periodontal maintenance patients. A randomized controlled clinical study. Photodiagnosis Photodyn. Ther. 2019, 27, 44-50. [CrossRef]

13. Grzech-Leśniak, K.; Matys, J.; Dominiak, M. Comparison of the clinical and microbiological effects ofantibiotic therapy in periodontal pockets following laser treatment: An in vivo study. Adv. Clin. Exp. Med. 2018, 27, 1263-1270. [CrossRef]

14. Grzech-Leśniak, K.; Nowicka, J.; Pajączkowska, M.; Matys, J.; Szymonowicz, M.K.; Kuropka, P.; Rybak, Z.; Dobrzyński, M.; Dominiak, M. Effects of Nd:YAG laser irradiation on the growth of Candida albicans and Streptococcus mutans: In vitro study. Lasers Med. Sci. 2018, 34, 129-137. [CrossRef] [PubMed]

15. Grzech-Leśniak, K.; Matys, J.; Jurczyszyn, K.; Ziółkowski, P.; Dominiak, M.; Junior, A.B.; Romeo, U. Histological and Thermometric Examination of Soft Tissue De-Epithelialization Using Digitally Controlled Er:YAG Laser Handpiece: An Ex Vivo Study. Photomed. Laser Surg. 2018, 36, 313-319. [CrossRef] [PubMed]

16. Świder, K.; Dominiak, M.; Grzech-Leśniak, K.; Matys, J. Efect of Different Laser Wavelengths on Periodontopathogens in Peri-Implantitis: A Review of In Vivo Studies. Microorganisms 2019, 7, 189. [CrossRef]

17. Kubasiewicz-Ross, P.; Hadzik, J.; Gedrange, T.; Dominiak, M.; Jurczyszyn, K.; Pitułaj, A.; Nawrot-Hadzik, I.; Bortkiewicz, O.; Fleischer, M. Antimicrobial Efficacy of Different Decontamination Methods as Tested on Dental Implants with Various Types of Surfaces. Med. Sci. Monit. 2020, 26. [CrossRef]

18. Merigo, E.; Rocca, J.-P.; Pinheiro, A.L.B.; Fornaini, C. Photobiomodulation Therapy in Oral Medicine: A Guide for the Prac-titioner with Focus on New Possible Protocols. Photobiomodul. Photomed. Laser Surg. 2019, 37, 669-680. [CrossRef] [PubMed]

19. Grzech-Lesniak, K. Making Use of Lasers in Periodontal Treatment: A New Gold Standard? Photomed. Laser Surg. 2017, 35, 513-514. [CrossRef] [PubMed]

20. Dompe, C.; Moncrieff, L.; Matys, J.; Grzech-Leśniak, K.; Kocherova, I.; Bryja, A.; Bruska, M.; Dominiak, M.; Mozdziak, P.; Skiba, T.H.I.; et al. Photobiomodulation-Underlying Mechanism and Clinical Applications. J. Clin. Med. 2020, 9, 1724. [CrossRef] [PubMed]

21. Riegel, R.; Sepion, L. Laser Therapy for the Equine Athlete; LiteCure LLC.: Newark, NJ, USA, 2007; pp. 7-71.

22. Hamblin, M.R.; Demidova, T.N. Mechanisms of low level light therapy. Mech. Low-Light Ther. 2006, 6140, 614001. [CrossRef]

23. Lee, S.Y.; Park, K.-H.; Choi, J.-W.; Kwon, J.-K.; Lee, D.R.; Shin, M.S.; Lee, J.S.; You, C.E.; Park, M.Y. A prospective, randomized, placebo-controlled, double-blinded, and split-face clinical study on LED phototherapy for skin rejuvenation: Clinical, profilometric, histologic, ultrastructural, and biochemical evaluations and comparison of three different treatment settings. J. Photochem. Photobiol. B Biol. 2007, 88, 51-67. [CrossRef]

24. Ravera, S.; Ferrando, S.; Agas, D.; De Angelis, N.; Raffetto, M.; Sabbieti, M.G.; Signore, A.; Benedicenti, S.; Amaroli, A. 1064 nm Nd:YAG laser light affects transmembrane mitochondria respiratory chain complexes. J. Biophotonics 2019, 12 , e201900101. [CrossRef] 
25. Lee, J.; Stavropoulos, A.; Susin, C.; Wikesjö, U.M. Periodontal Regeneration: Focus on Growth and Differentiation Factors. Dent. Clin. N. Am. 2010, 54, 93-111. [CrossRef]

26. Pugliese, L.S.; Medrado, A.P.; Reis, S.R.; Andrade, Z.D.A. The influence of low-level laser therapy on biomodulation of collagen and elastic fibers. Pesqui. Odontol. Bras. 2003, 17, 307-313. [CrossRef] [PubMed]

27. Saygun, I.; Karacay, S.; Serdar, M.; Ural, A.U.; Sencimen, M.; Kurtis, B. Effects of laser irradiation on the release of basic fibroblast growth factor (bFGF), insulin like growth factor-1 (IGF-1), and receptor of IGF-1 (IGFBP3) from gingival fibroblasts. Lasers Med. Sci. 2008, 23, 211-215. [CrossRef] [PubMed]

28. Janis, J.E.; Kwon, R.K.; LaLonde, D.H. A Practical Guide to Wound Healing. Plast. Reconstr. Surg. 2010, 125, 230e-244e. [CrossRef] [PubMed]

29. Holmes, D.I.R.; Zachary, I.C. Vascular endothelial growth factor regulates stanniocalcin-1 expression via neuro-pilin-1-dependent regulation of KDR and synergism with fibroblast growth factor-2. Cell. Signal. 2008, 20, 569-579. [CrossRef] [PubMed]

30. Carroll, J.D.; Milward, M.R.; Cooper, P.R.; Hadis, M.; Palin, W. Developments in low level light therapy (LLLT) for dentistry. Dent. Mater. 2014, 30, 465-475. [CrossRef]

31. Pini Prato, G.P.; Rotundo, R.; Magnani, C.; Soranzo, C. Tissue engineering technology for gingival augmentation procedures: A case report. Int. J. Periodontics Restor. Dent. 2000, 20, 552-559.

32. Żurek, J.; Dominiak, M.; Botzenhart, U.; Bednarz, W. The use of biostatic fascia lata high allograft as a scaffold for autologous culture of fibroblast-An in vitro study. Ann. Anat. 2015, 199, 104-108. [CrossRef]

33. Puzio, M.; Hadzik, J.; Błaszczyszyn, A.; Gedrange, T.; Dominiak, M. Soft tissue augmentation around dental implants with connective tissue graft (CTG) and xenogenic collagen matrix (XCM). 1-year randomized control trail. Ann. Anat. Anat. Anz. 2020, 230, 151484. [CrossRef]

34. Saczko, J.; Dominiak, M.; Kulbacka, J.; Chwiłkowska, A.; Krawczykowska, H. A simple and established method of tissue culture of human gingival fibroblasts for gingival augmentation. Folia Histochem. Cytobiol. 2008, 46, 117-119. [CrossRef]

35. Dominiak, M.; Saczko, J.; Gerber, H.; Rybak, Z.; Gredes, T. Use of primary culture of human fibroblasts in gingiva augmentation procedure. Biomed. Tech. 2010, 55, 331-334. [CrossRef]

36. Martin, P.; Nunan, R. Cellular and molecular mechanisms of repair in acute and chronic wound healing. Br. J. Dermatol. 2015, 173, 370-378. [CrossRef]

37. Yu, H.C.; Huang, F.-M.; Lee, S.-S.; Yu, C.-C.; Chang, Y.-C. Effects of fibroblast growth factor-2 on cell proliferation of cementoblasts. J. Dent. Sci. 2016, 11, 463-467. [CrossRef]

38. Posten, W.; Wrone, D.A.; Dover, J.S.; Arndt, K.A.; Silapunt, S.; Alam, M. Low-level laser therapy for wound healing: Mecha-nism and efficacy. Dermatol. Surg. 2005, 31, 334-339. [CrossRef]

39. Sajan, G.; Michael, R.H.; Heidi, A. Effect of red light and near infrared laser on the generation of reactive oxygen species in primary dermal fibroblasts. J. Photochem. Photobiol. B 2018, 188, 60-68.

40. Kim, H.P. Lightening up Light Therapy: Activation of Retrograde Signaling Pathway by Photobiomodulation. Biomol. Ther. 2014, 22, 491-496. [CrossRef] [PubMed]

41. Sommer, A.P.; Caron, A.; Fecht, H.-J. Tuning Nanoscopic Water Layers on Hydrophobic and Hydrophilic Surfaces with Laser Light. Langmuir 2008, 24, 635-636. [CrossRef] [PubMed]

42. Niemz, M.H.; Markolf, H. Laser-Tissue Interactions_Fundamentals and Applications; Springer Science \& Business Media: Berlin, Germany, 2007; pp. 77-78.

43. Chung, H.; Dai, T.; Sharma, S.K.; Huang, Y.-Y.; Carroll, J.D.; Hamblin, M.R. The Nuts and Bolts of Low-level Laser (Light) Therapy. Ann. Biomed. Eng. 2011, 40, 516-533. [CrossRef] [PubMed]

44. Ghazizadeh, M.; Tosa, M.; Shimizu, H.; Hyakusoku, H.; Kawanami, O. Functional Implications of the IL-6 Signaling Pathway in Keloid Pathogenesis. J. Investig. Dermatol. 2007, 127, 98-105. [CrossRef]

45. Uitto, J. IL-6 Signaling Pathway in Keloids: A Target for Pharmacologic Intervention? J. Investig. Dermatol. 2007, 127, 6-8. [CrossRef]

46. Huang, P.J.; Huang, Y.C.; Su, M.F.; Yang, T.Y.; Huang, J.R.; Jiang, C.P. In vitro observations on the influence of copper peptide aids for the LED photoirradiation of fibroblast collagen synthesis. Photomed. Laser Surg. 2007, 25, 183-190. [CrossRef] [PubMed]

47. Cannarozzo, G.; Silvestri, M.; Tamburi, F.; Sicilia, C.; Del Duca, E.; Scali, E.; Bennardo, L.; Nisticò, S.P. A new 675-nm laser device in the treatment of acne scars: An observational study. Lasers Med. Sci. 2021, 36, 227-231. [CrossRef] [PubMed]

48. Khan, I.; Tang, E.; Arany, P. Molecular pathway of near-infrared laser phototoxicity involves ATF-4 orchestrated ER stress. Sci. Rep. 2015, 5, 10581. [CrossRef]

49. Cobb, C.M. Lasers in Periodontics: A Review of the Literature. J. Periodontol. 2006, 77, 545-564. [CrossRef] [PubMed]

50. Desmoulière, A.; Darby, I.A.; Laverdet, B.; Bonté, F. Fibroblasts and myofibroblasts in wound healing. Clin. Cosmet. Investig. Dermatol. 2014, 7, 301-311. [CrossRef]

51. Illescas-Montes, R.; Melguizo-Rodríguez, L.J.; Manzano-Moreno, F.J.; García-Martínez, O.; Concepción, R.; Ramos-Torrecillas, J. Cultured Human Fibroblast Biostimulation Using a 940 nm Diode. Laser Mater. 2017, 10, 793. [CrossRef] [PubMed]

52. Kreisler, M.; Christoffers, A.B.; Willershausenm, B.; d'Hoedt, B. Low Level 809-nm Diode Laser-Induced In Vitro Stimulation of the Proliferation of Human Gingival Fibroblasts. Lasers Med. Sci. 2003, 18, 100-103. [CrossRef]

53. Illescas-Montes, R.; Melguizo-Rodríguez, L.; García-Martínez, O.; De Luna-Bertos, E.; Manzano-Moreno, F.J.; Ruiz, C.; RamosTorrecillas, J. Human Fibroblast Gene Expression Modulation Using 940 NM Diode Laser. Sci. Rep. 2019, 9, 1-7. [CrossRef] 
54. Engel, K.W.; Khan, I.; Arany, P. Cell lineage responses to photobiomodulation therapy. J. Biophotonics 2016, 9, 1148-1156. [CrossRef]

55. Gkogkos, A.S.; Karoussis, I.K.; Prevezanos, I.D.; Marcopoulou, K.E.; Kyriakidou, K.; Vrotsos, I.A. Effect of Nd:YAG Low Level Laser Therapy on Human Gingival Fibroblasts. Int. J. Dent. 2015, 2015, 1-7. [CrossRef]

56. Gutknecht, N.; Kanehl, S.; Moritz, A.; Mittermayer, C.; Lampert, F. Effects of Nd:YAG-laser irradiation on monolayer cell cultures Lasers Surg. Med. 1998, 22, 30-36. [CrossRef]

57. Almeida-Lopes, L.; Rigau, J.; Zangaro, R.A.; Guidugli-Neto, J.; Jaeger, M.M. Comparison of the low level laser therapy ef-fects on cultured human gingival fibroblasts proliferation using different irradiance and same fluence. Lasers Surg. Med. 2001, 29, 179-184. [CrossRef]

58. Sağlam, M.; Köseoğlu, S.; Pekbağrıyanık, T.; Savran, L.; Enhoş, S. Effects of high power-pulsed Nd:YAG laser irradiation on the release of transforming growth factor-beta (TGF- $\beta$ ) and vascular endothelial growth factor (VEGF) from human gingival fibroblasts. J. Cosmet. Laser Ther. 2017, 19, 469-474. [CrossRef] [PubMed]

59. Chen, Y.J.; Jeng, J.H.; Lee, B.S.; Chang, H.F.; Chen, K.C.; Lan, W.H. Effects of Nd:YAG laser irradiation on cultured human gingival fibroblasts. Lasers Surg. Med. 2000, 27, 471-478. [CrossRef]

60. Day, R.M.; Suzuki, Y.J. Cell Proliferation, Reactive Oxygen and Cellular Glutathione. Dose-Response 2005, 3, 425-442. [CrossRef] [PubMed]

61. Rastogi, R.P.; Kumar, A.; Tyagi, M.B.; Sinha, R.P. Molecular mechanisms of ultraviolet radiation-induced DNA damage and repair. J. Nucleic Acids 2010, 2010, 592980. [CrossRef]

62. Sage, E.; Girard, P.-M.; Francesconi, S. Unravelling UVA-induced mutagenesis. Photochem. Photobiol. Sci. 2012, 11, 74-80. [CrossRef] [PubMed]

63. Alba, M.N.; Gerenutti, M.; Yoshida, V.M.H.; Grotto, D. Clinical comparison of salicylic acid peel and LED-Laser photo-therapy for the treatment of Acne vulgaris in teenagers. J. Cosmet. Laser Ther. 2017, 19, 49-53. [CrossRef] [PubMed]

64. Masson-Meyers, D.S.; Bumah, V.V.; Enwemeka, C.S. Blue light does not impair wound healing in vitro. J. Photochem. Photobiol. B Biol. 2016, 160, 53-60. [CrossRef] [PubMed]

65. De Sousa, N.T.A.; Santos, M.F.; Gomes, R.C.; Brandino, H.E.; Martinez, R.; Guirro, R.R.J. Blue Laser Inhibits Bacterial Growth of Staphylococcus aureus, Escherichia coli, and Pseudomonas aeruginosa. Photomed. Laser Surg. 2015, 33, 278-282. [CrossRef]

66. Trelles, M.A.; Allones, I.; Mayo, E. Combined visible light and infrared light-emitting diode (LED) therapy enhances wound healing after laser ablative resurfacing of photodamaged facial skin Medical. Laser Appl. 2006, 21, 165-175. [CrossRef] 